\title{
DENGUE FEVER- ITS CLINICAL PROFILE, RADIOLOGICAL FINDINGS, HAEMATOLOGICAL AND BIOCHEMICAL PARAMETERS - STUDY FROM A TERTIARY CARE HOSPITAL
}

\author{
Gudi Srinivas ${ }^{1}$, Yarram Rajeswara Rao ${ }^{2}$
}

${ }_{1}^{1}$ Associate Professor, Department of General Medicine, Rajiv Gandhi Institute of Medical Sciences, Ongole, Andhra Pradesh.

${ }^{2}$ Assistant Professor, Department of General Medicine, Rajiv Gandhi Institute of Medical Sciences, Ongole, Andhra Pradesh.

ABSTRACT
BACKGROUND
Dengue is a rapidly progressing self-limiting systemic viral infection transmitted between humans by mosquitoes. About two-fifth
of world's population, mostly those in tropical and sub-tropical countries are at a risk of dengue infection.

\section{MATERIALS AND METHODS}

A hospital-based cross-sectional descriptive study was conducted in Rajiv Gandhi Institute of Medical Sciences, Ongole. A total of 233 patients who were clinically diagnosed cases of Dengue with subsequent confirmation by Dengue NS1 Ag/ Dengue IgM were selected in the study. Data was collected using a semi-structured questionnaire, either by direct interview with patients or patient's relatives and by clinical examination and from relevant investigations.

\section{RESULTS}

Out of the 233 study population, majority $(44.6 \%, n=104)$ belonged to $40-59$ years age group. Fever was the most common presenting symptom (99.6\%) in the present study followed by myalgia in $60 \%$, headache in $43.8 \%$, joint pain in $35.6 \%$ and backache in $28.8 \%$. Majority had low platelet count (68.2\%). SGPT was altered in $65.2 \%$, serum albumin in $33 \%$ and SGOT in $73.7 \%$ of the patients. $16.7 \%$ of patients had high random blood sugar level and $7.3 \%$ had high serum amylase levels. Dengue NS1 antigen was positive in $187(80.3 \%)$ patients and $50(21.5 \%)$ had dengue IgM positivity. The most common radiological finding in the present study was gall bladder wall oedema, which constituted $19.3 \%$ cases followed by ascites (9.4\%), pleural effusion (9.5\%), free fluid in Morrison pouch/ pelvis (2.6\%) and pancreatitis (2.6\%).

\section{CONCLUSION}

Ultrasonographic features like gall bladder wall oedema, pleural effusion and ascites should strongly favour diagnosis of dengue fever in a patient who presents with fever and thrombocytopenia, especially during an epidemic.

\section{KEYWORDS}

Dengue Fever, Clinical, Radiological, Haematological, Biochemical Parameters.

HOW TO CITE THIS ARTICLE: Srinivas G, Rao YR. Dengue fever- its clinical profile, radiological findings, haematological and biochemical parameters- study from a tertiary care Hospital. J. Evolution Med. Dent. Sci. 2018;7(13):1588-1591, DOI: $10.14260 /$ jemds/2018/359

\section{BACKGROUND}

Dengue is a rapidly progressing self-limiting systemic viral infection transmitted between humans by mosquitoes. Around two-fifth of world's population, mostly those in tropical and sub-tropical countries, are at a risk of dengue infection.[1] Globally, about 390 million infections, of which 96 million symptomatic cases occur yearly.[2] The region with the highest dengue incidence is in South East Asia, where cycles of epidemics occur every $3-5$ years.[3] About 1.8 billion of the population at risk for dengue worldwide live in South East Asia Region and Western Pacific Region. Of the 11 countries in South East Asia region, 10 are endemic for dengue and this includes India too. In India, unplanned urbanisation, migration of people from rural to urban areas with lack of proper sanitation are the main factors resulting in increased burden of dengue in recent times.[4]

'Financial or Other Competing Interest': None.

Submission 28-02-2018, Peer Review 11-03-2018,

Acceptance 14-03-2018, Published 26-03-2018.

Corresponding Author:

Dr. Yarram Rajeswara Rao,

House No. 37-1-383 (112),

Indira Colony, Opp. Dr. Ambedkar Bhavan,

Ongole, Prakasam-523001

Andhra Pradesh.

E-mail: yarram.rajeswararao@gmail.com

DOI: $10.14260 /$ jemds $/ 2018 / 359$
Over the past 50 years global incidence of dengue has increased 30 times.[5] In the past 2 decades, there has been a global increase in the frequency of dengue fever, dengue haemorrhagic fever and its epidemic due to rapid human population growth, uncontrolled urbanisation, inadequate waste and water management, and lack of effective mosquito control.[6] About $85 \%$ of dengue infections are asymptomatic and rest $15 \%$ evolve to febrile illness, about 50,000 dengue cases progress to life-threatening disease causing 20,000 to 25,000 deaths annually.[7] The acute illness experienced by dengue patients even though of short duration and not always life-threatening could have an important impact on daily activities, social function and emotional well-being. ${ }^{[8]}$

In India, the disease is now epidemic in the entire country. As per the national programme, a total of 74,201 cases of dengue and 167 deaths in 2013 were reported. In 2015, Delhi, India, recorded its worst outbreak since 2006 with over 15,000 cases. The magnitude of the problem is much high, as the estimates are only on the reported cases. $[9,10]$

According to National Vector-Borne Disease Control Programme, total dengue cases in India were 1,29,166 in 2016 and 1,57,220 in 2017. Total deaths in India were 245 and 250 in 2016 and 2017 respectively. In Andhra Pradesh, total cases were 3,417 in 2016 and 4,776 in 2017. 
The present study has been done with an objective to determine the clinical profile among patients diagnosed with dengue fever and to assess the radiological findings, haematological and biochemical parameters from a tertiary care hospital.

\section{MATERIALS AND METHODS}

\section{Study Design}

Hospital-based cross-sectional study.

\section{Study Setting}

Rajiv Gandhi Institute of Medical Sciences, Ongole.

\section{Study Period}

January 2016 to December 2017.

\section{Study Subjects}

Include all adult patients aged 14 years and above who were admitted in medical wards of the Department of Medicine.

\section{Inclusion Criteria}

Clinically diagnosed cases of Dengue with subsequent confirmation by Dengue NS1 Ag/ Dengue IgM.

\section{Sample Size and Sampling Technique}

A total of 233 patients were selected for the study by consecutive sampling technique.

\section{Study Procedure}

The patients were selected as per inclusion criteria. An informed consent was taken. Detailed case history was taken, and relevant investigations were done for all patients at the time of admission itself.

Data was collected using a semi-structured questionnaire, either by direct interview with patients or patient's relatives and by clinical examination and from relevant investigations.

\section{Investigations}

a. Complete haemogram.

b. Biochemical parameters including liver function test, renal function test, serum amylase, urine routine examination.

c. Serology- Dengue NS1 Ag and IgM ELISA dengue.

d. Radiological investigations- Chest x-ray, USG abdomen, ECG, ECHO scan. Neuroimaging (CT/ MRI Brain) done in selected patients only.

\section{Statistical Analysis}

Statistical analysis was done using Microsoft Excel 2010 version. Descriptive statistics was carried out by mean and standard deviation for quantitative variables, frequency and proportion for categorical variables.

\section{RESULTS}

The mean age of the study population was 44.09 years with a standard deviation of 15.72 with majority (44.6\%) subjects belonging to 40 - 59 years' age group. The proportion of males and females was $51.9 \%$ and $48.1 \%$ with a male-tofemale ratio of 1.08: 1 .
Majority of the subjects were admitted in the month of October $(53.2 \%)$ followed by November (24.9\%), September (13.7\%) and December (6\%).

The duration of admission ranged from 1 to 22 days with mean duration of $6.44 \pm 2.87$ days with maximum proportion of patients admitted for less than 10 days.

Fever was the most common presenting symptom $(99.6 \%)$ in the present study followed by myalgia in $60 \%$, headache in $43.8 \%$, joint pain in $35.6 \%$ and backache in $28.8 \%$. Other symptoms in decreasing order are vomiting in $27 \%$, retro-orbital pain in $16 \%$, pruritus in $14 \%$, abdominal pain in $10.3 \%$, cough in $8.6 \%$, loose stool in $6.9 \%$, rash in $6 \%$ and dysuria in $5 \%$ patients.

Among bleeding manifestations, menorrhagia (4\%) was the most common followed by melena in $2.1 \%$, haemoptysis in $1.7 \%$, epistaxis in $1.3 \%$ and haematemesis in $0.9 \%$ of the study population.

\begin{tabular}{|c|c|c|}
\hline Categories & Number & Percentage \\
\hline Anaemia & 54 & $23.2 \%$ \\
\hline $\begin{array}{c}\text { Low total leukocyte } \\
\text { count }\end{array}$ & 121 & $51.9 \%$ \\
\hline Low platelet count & 159 & $68.2 \%$ \\
\hline High urea & 04 & $1.7 \%$ \\
\hline High creatinine & 15 & $6.4 \%$ \\
\hline Urine albumin +ve & 08 & $3.4 \%$ \\
\hline High SGPT & 152 & $65.2 \%$ \\
\hline Low S. albumin & 77 & $33 \%$ \\
\hline High SGOT & 172 & $73.7 \%$ \\
\hline High S. amylase & 17 & $7.3 \%$ \\
\hline High RBS & 39 & $16.7 \%$ \\
\hline \multicolumn{3}{|c|}{ Table 1. Summary of the Laboratory Parameters } \\
\hline
\end{tabular}

Anaemia was seen in $23.2 \%$ of dengue fever patients in the study. Majority (51.9\%) had TLC less than 4000. Majority had low platelet count $(68.2 \%)$. Out of the 233 cases of dengue fever, $13.7 \%$ patients had a platelet count less than 29,000 .

Blood urea and serum creatinine were high in $1.7 \%$ and $6.4 \%$ of the patients respectively.

Among the Liver function tests SGPT was altered in $65.2 \%$, serum albumin in $33 \%$, SGOT in $73.7 \%$ of the patients. $16.7 \%$ of patients had high random blood sugar level and $7.3 \%$ had high serum amylase levels.

Dengue NS1 antigen was positive in 187 (80.3\%) of patients and $50(21.5 \%)$ had dengue IgM positivity.

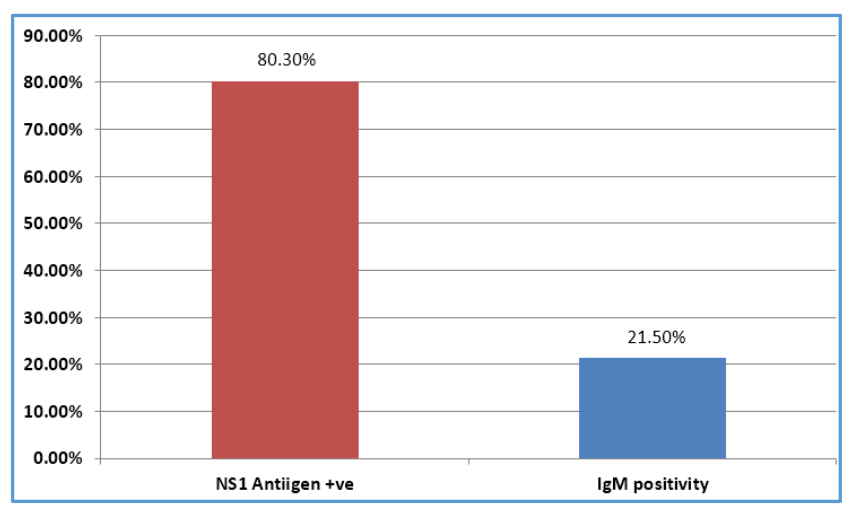

Figure 1. Bar Chart of Serology in Study Group 


\begin{tabular}{|c|c|c|}
\hline Categories & Number & Percentage \\
\hline ECG Sinus Bradycardia & 56 & $24 \%$ \\
\hline $\begin{array}{l}\text { Chest X-ray } \\
\text { Left lower lobe } \\
\text { consolidation } \\
\text { Pleural effusion }\end{array}$ & $\begin{array}{l}06 \\
06\end{array}$ & $\begin{array}{l}2.6 \% \\
2.6 \%\end{array}$ \\
\hline $\begin{array}{c}\text { Echocardiogram } \\
\text { Pericardial effusion }\end{array}$ & 03 & $1.3 \%$ \\
\hline \multicolumn{3}{|c|}{ Other Radiological Findings } \\
\hline Gall bladder oedema & 48 & $19.3 \%$ \\
\hline Ascites & 22 & $9.4 \%$ \\
\hline Pleural effusion & 22 & $9.4 \%$ \\
\hline $\begin{array}{l}\text { Free fluid Morrison } \\
\text { pouch/ pelvis }\end{array}$ & 06 & $2.6 \%$ \\
\hline Pancreatitis & 06 & $2.6 \%$ \\
\hline \multicolumn{3}{|c|}{ Table 2. Radiological and Other Investigations } \\
\hline
\end{tabular}

In the present study, sinus bradycardia as an ECG finding was seen in $24 \%$ cases. Chest x-ray was normal in 221 $(94.8 \%)$ patients, $6(2.6 \%)$ patients each had left lower lobe consolidation and pleural effusion. Pericardial effusion on echocardiogram was seen in $1.3 \%$ patients.

The most common radiological finding in the present study was gall bladder wall oedema which constituted 19.3\% cases followed by ascites (9.4\%), pleural effusion (9.5\%), free fluid in Morrison pouch/ pelvis (2.6\%) and pancreatitis (2.6\%).

\section{DISCUSSION}

In the present study of 233 patients of dengue fever, males were affected more than females. 121 were males and 112 were females, which constitute to $51.9 \%$ and $48.1 \%$ respectively and the ratio being 1.08: 1 .

\begin{tabular}{|c|c|c|c|c|c|c|c|}
\hline $\begin{array}{l}\vec{E} \\
\vec{\infty}\end{array}$ & 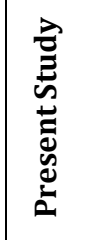 & 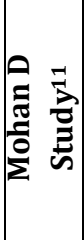 & 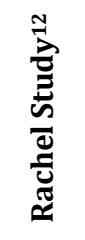 & 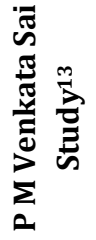 & 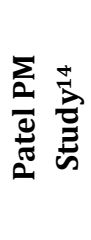 & 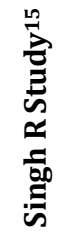 & 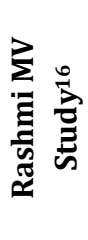 \\
\hline Males & 121 & 54 & 130 & 80 & 152 & 80 & 62 \\
\hline Females & 112 & 46 & 120 & 48 & 98 & 60 & 38 \\
\hline \begin{tabular}{|c|} 
Male: \\
Female
\end{tabular} & 1.08:1 & 1.17 & 1.08 & 1.67 & 1.55 & 1.33 & 1.63 \\
\hline \multicolumn{8}{|c|}{$\begin{array}{c}\text { Table 3. In Study of Dengue Fever Male-to-Female Ratio in } \\
\text { Different Studies }\end{array}$} \\
\hline
\end{tabular}

The results of Rachel Daniel[12] was similar to present study. The patient's age ranged from 14 years to 90 years with mean age of $44.09 \pm 15.72$ yrs.

The maximum prevalence of dengue fever was noted in age group of 40 - 59 yrs. of about $44.6 \%$. The least number were in $>80$ years' age group with $1.3 \%$ accounting for it.

The duration of admission ranged from 1 to 22 days with mean duration of $6.44 \pm 2.87$ days.

The maximum number of patients got admitted in October $(53.2 \%)$ followed by November $(24.9 \%)$, September $(13.7 \%)$, December $(6 \%)$ in the present study, whereas the maximum number of admissions are in September $(27.1 \%)$ in Singh R study[15] followed by October (25\%), November (20\%) and August (19\%).
Almost all patients in the study presented with fever. Other than fever, myalgia was the most common symptom in $60.9 \%$ followed by headache $(43.8 \%)$, joint pain $(35.6 \%)$, backache $(28.8 \%)$, vomiting $(27 \%)$, retro-orbital pain $(16 \%)$, pruritus (14\%), abdominal pain (10.3\%), cough (8.6\%), loose stool (6.9\%), rash (6\%) and dysuria (5\%). Similar findings were seen in other studies- Mohan D Kashinkunti[11] study, Rachel study,[12] Singh R study[15] and Ashwini Kumar study.[17]

The bleeding manifestations constituted $10 \%$ of the present study, whereas $15.2 \%$ of cases in Rachel study, ${ }^{[12]}$ $21 \%$ in Mohan D study ${ }^{[11]}$ and $11.4 \%$ in Singh R study.[15]

In present study patients with platelet counts > $1,50,000 /$ cumm in $31.3 \%, 32.2 \%$ in $90,000-1,50,000 /$ cumm, $15 \%$ in $60,000-89,000,7.7 \%$ in $30,000-59,000 /$ cumm, $13.7 \%$ in $<29,000 /$ cumm.

\begin{tabular}{|c|c|c|c|c|c|}
\hline Study & $\begin{array}{c}\text { Present } \\
\text { Study }\end{array}$ & $\begin{array}{c}\text { Patel } \\
\text { PM } \\
\text { Study }\end{array}$ & $\begin{array}{c}\text { Rachel } \\
\text { Daniel } \\
\text { Study12 }\end{array}$ & $\begin{array}{c}\text { Singh R } \\
\text { Study } \mathbf{1 5}\end{array}$ & $\begin{array}{c}\text { Shaista } \\
\text { Choudhary } \\
\text { Study }\end{array}$ \\
\hline$<1,00,000$ & $39.5 \%$ & $59 \%$ & $90 \%$ & $41.4 \%$ & $90 \%$ \\
\hline$<50,000$ & $19.31 \%$ & - & $47.4 \%$ & $27.1 \%$ & $60 \%$ \\
\hline Table 4. Comparison of Platelet Count in Present Study \\
with Other Studies \\
\hline
\end{tabular}

The results of Singh R study[15] is similar to present study.

\begin{tabular}{|c|c|c|c|c|c|}
\hline Study & $\begin{array}{c}\text { Present } \\
\text { Study }\end{array}$ & $\begin{array}{c}\text { Patel } \\
\text { PM } \\
\text { Study }\end{array}$ & $\begin{array}{c}\text { Rachel } \\
\text { Daniel } \\
\text { Study }\end{array}$ & $\begin{array}{c}\text { Singh R } \\
\text { Study }\end{array}$ & $\begin{array}{c}\text { Shaista } \\
\text { Choudhary } \\
\text { Study }\end{array}$ \\
\hline SGPT & $65.2 \%$ & $40 \%$ & - & $41.4 \%$ & $64 \%$ \\
\hline SGOT & $73.7 \%$ & - & $83.9 \%$ & $80 \%$ & $64 \%$ \\
\hline S. albumin & $33.05 \%$ & - & - & - & - \\
\hline
\end{tabular}

Table 5. Comparison of Alterations in Liver Function Test in Present Study with Other Studies

The result of Patel PM study[14] and Singh R study ${ }^{[15]}$ are similar to that of the present study.

Sinus bradycardia as an ECG finding constituted $25 \%$ cases in present study, whereas $15 \%$ in Rachel study.[12]

\begin{tabular}{|c|c|c|c|c|c|}
\hline $\begin{array}{c}\text { Ultrasound } \\
\text { Finding }\end{array}$ & $\begin{array}{c}\text { Present } \\
\text { Study }\end{array}$ & $\begin{array}{c}\text { VR } \\
\text { Santhosh } \\
\text { Study } 19\end{array}$ & $\begin{array}{c}\text { Venkata } \\
\text { Stui }\end{array}$ & $\begin{array}{c}\text { Singh } \\
\text { R } \\
\text { Study }\end{array}$ & $\begin{array}{c}\text { Basawaraj } \\
\text { NG } \\
\text { Study }^{20}\end{array}$ \\
\hline $\begin{array}{c}\text { Gall bladder } \\
\text { wall oedema }\end{array}$ & $19.3 \%$ & $66.7 \%$ & $100 \%$ & $12.9 \%$ & $92.8 \%$ \\
\hline Ascites & $9.4 \%$ & $64.5 \%$ & - & $38.6 \%$ & $93.3 \%$ \\
\hline $\begin{array}{c}\text { Pleural } \\
\text { effusion }\end{array}$ & $9.4 \%$ & $48 \%$ & $6.25 \%$ & $12.9 \%$ & $29.5 \%$ \\
\hline Hepatomegaly & - & $17 \%$ & $21.8 \%$ & $43.6 \%$ & $66 \%$ \\
\hline Splenomegaly & - & $16 \%$ & $6.25 \%$ & $30 \%$ & $50 \%$ \\
\hline Pancreatitis & $2.6 \%$ & - & - & - & - \\
\hline $\begin{array}{c}\text { Free fluid in } \\
\text { pelvis }\end{array}$ & $2.6 \%$ & - & - & - & - \\
\hline $\begin{array}{c}\text { Table 6. Comparison of Ultrasound Findings in Present } \\
\text { Study with Other Studies }\end{array}$ \\
\hline
\end{tabular}

\section{CONCLUSION}

Strong possibility of dengue fever should be kept in mind in any patient presenting with fever, myalgia, joint pain, headache and backache. Ultrasonographic features like Gall bladder wall oedema, pleural effusion and ascites should strongly favour diagnosis of dengue fever in a patient who 
presents with fever and thrombocytopenia, especially during an epidemic. It helps in making the diagnosis of dengue fever in patients awaiting their serological reports.

\section{REFERENCES}

[1] WHO. Comprehensive Guidelines for Prevention and Control of Dengue and Dengue Haemorrhagic Fever. Revised and expanded edition. WHO, 2011: p. 196.

[2] Bhatt S, Gething PW, Brady OJ, et al. The global distribution and burden of dengue. Nature 2013;496(7446):504-7.

[3] Shepard DS, Undurraga EA, Halasa YA. Economic and disease burden of dengue in Southeast Asia. PLoS Neglected Tropical Diseases 2013;7(2):e2055. https://doi.org/10.1371/journal.pntd.0002055

[4] Bennett SN, Holmes EC, Chirivella M, et al. Selectiondriven evolution of emergent dengue virus. Mol Biol Evol 2003;20(10):1650-8.

[5] Dengue Guidelines for diagnosis, treatment, prevention and control, 2009. Chapter 1. A joint publication of the WHO and Special Programme for Research and Training in Tropical Diseases (TDR). 2009: p. 3.

[6] Guideline for clinical management of dengue fever, dengue haemorrhagic fever and dengue shock syndrome. Chapter 1. Directorate of National Vector Borne Diseases Control Programme, Directorate General of Health Services, Ministry of Health \& Family Welfare, Delhi, Govt. of India, 2008: p. 1.

[7] Gibbons RV, Vaughn DW. Dengue: an escalating problem. BMJ 2002;324(7353):1563-6.

[8] Lum LCS, Suaya JA, Tan LH, et al. Quality of life of dengue patients. The American Journal of Tropical Medicine and Hygiene 2008;78(6):862-7.

[9] WHO fact sheets on Dengue 2017. http://www.who.int/mediacentre/factsheets/fs117/e $\mathrm{n} /$ (last accessed on 02-02-2018)
[10] Mutheneni SR, Morse AP, Caminade C, et al. Dengue burden in India: recent trends and importance of climatic parameters. Emerging Microbes \& Infections 2017;6(8):e70. doi:10.1038/emi.2017.57.

[11] Kashinkunti MD, Shiddappa, Dhananjaya M. A study of clinical profile of dengue fever in a tertiary care teaching hospital. Sch J App Med Sci 2013;1(4):280-2.

[12] Daniel R, Rajamohanan, Philip AZ. A study of clinical profile of Dengue fever in Kollam, Kerala, India. Dengue Bulletin 2005;29:197-202.

[13] Venkata Sai PM, Dev B, Krishnan R. Role of ultrasound in dengue fever. Br J Radiol 2005;78(929):416-8.

[14] Patel PM, Patel SK, Sabalpara MA, et al. Study of hematological and biochemical changes in dengue fever at tertiary care hospital at Ahmedabad. Int J Med Sci Public Health 2016;5(9):1934-6.

[15] Singh R, Singh SP, Ahmad N. A study of clinical and laboratory profile of dengue fever in a tertiary care centre of Uttarakhand, India. Int J Res Med Sci 2014;2(1):160-3.

[16] Rashmi MV, Hamsaveena. Haematological and biochemical markers as predictors of dengue infection. Malays J Pathol 2015;37(3):247-51.

[17] Kumar A, Rao CR, Pandit V, et al. Clinical manifestations and trend of dengue cases admitted in a tertiary care hospital, Udupi District, Karnataka. Indian J Community Med 2010;35(3):386-90.

[18] Choudhary S, Shivkumar BR, Shankar A, et al. Haematological changes in dengue fever. National Journal of Basic Medical Sciences 2011;3(4):289-93.

[19] Santhosh VR, Patil PG, Srinath MG, et al. Sonography in the diagnosis and assessment of Dengue fever. J Clin Imaging Sci 2014;4:14.

[20] Basawaraj NG, Dasan TA, Patil SS, et al. Role of sonography in the assessment of dengue fever with serological correlation. Int J Res Med Sci 2015;3(11):3131-6. 